\title{
Differential androgen and estrogen substrates specificity in the mouse and primates type $1217 \beta$-hydroxysteroid dehydrogenase
}

\author{
Pierre-Gilles Blanchard and Van Luu-The \\ Oncology and Molecular Endocrinology Research Center, Laval University Hospital Research Center (CRCHUL) and Laval University, 2705 Laurier Boulevard, \\ Quebec, G1V 4G2, Canada \\ (Requests for offprints should be addressed to V Luu-The; Email: van.luu-the@crchul.ulaval.ca)
}

\begin{abstract}
Recently, we have shown that human and monkey type 12 $17 \beta$-hydroxysteroid dehydrogenases (17 $\beta$-HSD12) are estrogen-specific enzymes catalyzing the transformation of estrone $\left(E_{1}\right)$ into estradiol $\left(E_{2}\right)$. To further characterize this novel steroidogenic enzyme in an animal model, we have isolated a cDNA fragment encoding mouse $17 \beta-H S D 12$ and characterized its enzymatic activity. Using human embryonic kidney cells (HEK)-293 cells stably expressing mouse 17ß-HSD12, we found that in contrast with the human and monkey enzymes, which are specific for the transformation of $\mathrm{E}_{1}$ to $\mathrm{E}_{2}$, mouse $17 \beta$-HSD12 also catalyzes the transformation of 4androstenedione into testosterone $(\mathrm{T})$, dehydroepiandrosterone (DHEA) into 5-androstene-3 $\beta, 17 \beta$-diol (5-diol), as well as androsterone into $5 \alpha$-androstane- $3 \alpha, 17 \beta$-diol ( $3 \alpha$-diol). Previously, we have shown that the specificity of human and monkey $17 \beta-H S D 12$ s for C18-steroid is due to the presence of a bulky phenylalanine (F) at position 234 creating steric hindrance, preventing the entrance of C19-steroids into the
\end{abstract}

active site. To determine whether the smaller size of the corresponding leucine (L) in the mouse sequence is responsible for the entrance of androgenic substrates, we performed site-directed mutagenesis to substitute Leu 234 for Phe in the mouse enzyme. In agreement with our hypothesis, the mutated enzyme has a highly reduced ability to metabolize androgens. mRNA quantification in several mouse tissues using real-time PCR shows that mouse $17 \beta-$ HSD12 mRNA is highly expressed in the female clitoral gland, male preputial gland, as well as in retroperitoneal fat and adrenal of both sexes. The differential androgenic/estrogenic substrate specificity of type $1217 \beta-\mathrm{HSD}$ in the mouse and primates seems to agree with the observation that androgen and estrogen in the mouse are provided almost exclusively by gonads, while in primates an important part of these steroid hormones are produced locally from adrenal precursors.

Journal of Endocrinology (2007) 194, 449-455

\section{Introduction}

Active sex steroids (testosterone, dihydrotestosterone, and estradiol $\left(\mathrm{E}_{2}\right)$ ) are characterized by the presence of a hydroxyl group at position $17 \beta$ on the steroid nucleus. The formation of the $17 \beta$-hydroxy group is catalyzed by $17 \beta$-hydroxysteroid dehydrogenases (17 $\beta$-HSDs). To date, 14 types of $17 \beta$-HSDs have been identified (Peltoketo et al. 1999, Luu-The 2001, Mindnich et al. 2004). In the human, a clear substrate specificity pattern for estrogen and androgen substrates has been observed. Types 1, 7, and $1217 \beta$-HSDs (17 $\beta$-HSD1, $17 \beta-H S D 7$, and $17 \beta$-HSD12) catalyze the transformation of estrone $\left(\mathrm{E}_{1}\right)$ into $\mathrm{E}_{2}$, while $17 \beta-\mathrm{HSD} 3$ and $17 \beta-\mathrm{HSD} 5$ are able to catalyze the transformation of 4-androstenedione (4-dione) into testosterone $(\mathrm{T})$. Others catalyze mostly the transformation of $5 \alpha$-reduced C19-steroids. In rodents, the enzymatic characteristics of steroidogenic enzymes are somehow different from their human counterparts. For example, rodent $17 \beta-H S D 1$ catalyzes, in addition to the formation of $E_{2}$ from $\mathrm{E}_{1}$, the transformation of 4-dione into $\mathrm{T}$ while human
$17 \beta-H S D 1$ catalyzes selectively the transformation of $E_{1}$ into $E_{2}$. In the human, the enzyme is abundantly expressed in the placenta where it exerts its function as a partner of aromatase, which is also abundantly expressed to produce $\mathrm{E}_{2}$. In the rodent, $17 \beta-$ HSD1 and aromatase are absent from the placenta and thus rodent placenta does not produce $\mathrm{E}_{2}$ (Gibori et al. 1988). The production of $\mathrm{E}_{2}$ in rodents is provided by granulosa cells (Mustonen et al. 1997, Nokelainen et al. 1998). Indeed, 17 $\beta-H S D 1$ is expressed in granulosa and cumulus cells in both the human (Sawetawan et al. 1994) and rodents (Ghersevich et al. 1994a,b, Nokelainen et al. 1998).

It is noteworthy that human type $717 \beta-H S D$, in addition to its ability to catalyze the transformation of $E_{1}$ into $E_{2}$, also possesses 3-ketoreductase activity able to transform dihydroxy testosterone (DHT) into $5 \alpha$-androstane-3 $\beta, 17 \beta$-diol ( $3 \beta$-diol; Torn et al. 2003, Liu et al. 2005) and zymosterone into zymosterol, an important step in the cholesterol biosynthetic pathway (Marijanovic et al. 2003).

Recently, we have characterized primate and human 17ß-HSD12 (Luu-The et al. 2006, Liu et al. 2007) that 
share high homology with $17 \beta-$ HSD 3 and found that both $17 \beta-H S D 12 s$ catalyze selectively the transformation of $E_{1}$ into $E_{2}$, thus suggesting that this enzyme is most probably an important partner of aromatase in the biosynthesis of $E_{2}$. Indeed, the two steps that are specific for $\mathrm{E}_{2}$ biosynthesis are the aromatization of 4-dione precursor into $\mathrm{E}_{1}$ (a weak estrogen) followed by the transformation of $E_{1}$ into $E_{2}$, the most potent natural estrogen, by estrogenic $17 \beta-\mathrm{HSD}$. The isolation of cDNAs encoding enzymes that are specific for the conversion of $E_{1}$ into $E_{2}$ (human 17 $\beta-H S D 1$, $17 \beta-H S D 7$, and $17 \beta-H S D 12)$ seems to agree with this model, suggesting strongly that the step of reduction by $17 \beta$-HSD follows the step of aromatization (Luu-The et al. 2006). It is noteworthy that data of Moon \& Horton (2003) also suggest that $17 \beta-\mathrm{HSD} 12$ could be involved in the twocarbon fatty acyl elongation cascade.

In this report, we describe the characterization of mouse $17 \beta$-HSD12. We show that, similar to $17 \beta-H S D 1$, mouse $17 \beta-$ HSD12 is also able to catalyze the transformation of C19-steroids, which is in contrast with the corresponding human enzymes that are selective for estrogenic substrates. The role of the amino acid at position 234 of $17 \beta-H S D 12$ in substrate selectivity and the mRNA expression levels in different mouse tissues are also investigated.

\section{Materials and Methods}

\section{Tissue collection and RNA preparation}

C57BL6 mice at 12-15 weeks of age were obtained from Charles River Inc. (Saint-Constant, Que., Canada) and housed individually in vinyl cages where the photoperiods were $12 \mathrm{~h}$ light: $12 \mathrm{~h}$ darkness. The mice were provided with certified rodent food (Lab Rodent Diet) and tap water available ad libitum. The experiment was conducted in an animal facility approved by the Canadian Council on Animal Care (CCAC) and the Association for Assessment and Accreditation of Laboratory Animal Care and performed in accordance with the CCAC Guide for Care and Use of Experimental Animals. During the tissue collection, organs were rapidly trimmed, snap-frozen in liquid nitrogen, and stored at $-80^{\circ} \mathrm{C}$. Total RNA was isolated by Trizol (Invitrogen). Using oligo-d(T)24 as primer in a reaction buffer containing $50 \mathrm{mM}$ Tris- $\mathrm{HCl}(\mathrm{pH} 8 \cdot 3), 75 \mathrm{mM} \mathrm{KCl}$, $3 \mathrm{mM} \mathrm{MgCl} 2,10 \mathrm{mM}$ dithiothreitol, and $0.5 \mathrm{mM}$ dNTPs, $20 \mu \mathrm{g}$ RNA were then converted to cDNA by incubation at $42{ }^{\circ} \mathrm{C}$ for $1 \mathrm{~h}$ with $400 \mathrm{U}$ SuperScript II reverse transcriptase (Invitrogen).

\section{Isolation of mouse $17 \beta$-HSD12 and construction of $p C M V$ neo- HSD17B12 vector}

To amplify a cDNA fragment containing the entire coding region of mouse $17 \beta-H S D 12$ by RT-PCR, we used the oligonucleotide primers $\left(5^{\prime}\right.$-ggg-gaa-ttc-gcc-atg-gag-tgc- gct-ccc-ccg-gcg- $\left.3^{\prime}\right)$ and $\left(5^{\prime}\right.$-ggg-tct-aga-tta-gtt-ctt-ctt-cctttt-ctt-cag-gta-g- $3^{\prime}$ ) derived from the GenBank sequence having accession number NM_019657. The resulting cDNA fragment was then subcloned into a pCMVneo vector, downstream of a cytomegalo virus (CMV) promoter. To verify the integrity of the new construct, namely pCMVneomHSD17B12, we sequenced it before stably transfecting into HEK-293 cells as described (Huang \& Luu-The 2000).

Assay of enzymatic activity in intact HEK-293 cells stably expressing mouse $17 \beta$-HSD12

Enzymatic activity measurements were performed in intact cells as previously described (Dufort et al. 2001). Cells were plated in 6 -well plates to $\sim 5 \times 10^{5} /$ well in minimum essential medium (MEM). Briefly, $0 \cdot 1 \mu \mathrm{M}$ of the $\left({ }^{14} \mathrm{C}\right)$ labeled steroids (Dupont Inc., Mississauga, Ont., Canada) was added to freshly changed culture medium. After incubation, steroids were extracted with $2 \mathrm{ml}$ ether and evaporated to dryness. The steroids were then dissolved in $50 \mu \mathrm{l}$ dichloromethane, applied to silica gel 60 thin layer chromatography plates (Merck), before separation by migration in the toluene/acetone (4:1) solvent system. Substrates and metabolites were identified by comparison with reference steroids, revealed by autoradiography, and quantified using the PhosphoImager System (Molecular Dynamics Inc., Sunnyvale, CA, USA).

\section{Site-directed mutagenesis}

In order to replace the $\mathrm{L}$ at amino acid position 234 in the mouse $17 \beta-H S D 12$ with an $\mathrm{A}$ or $\mathrm{F}$ residue, we performed site-directed mutagenesis using the Quick Change Sitedirected Mutagenesis kit (Stratagene, La Jolla, CA, USA) as described (Dufort et al. 1999) and the following oligonucleotide primers: $5^{\prime}$-agt-gtc-atg-cca-tac-gct-gta-gct-aca-aaa$\operatorname{ctg}-3^{\prime}$ and its complementary sequence for L234A substitution, and $5^{\prime}$-agt-gtc-atg-cca-tac-ttt-gta-gct-aca-aaactg- $3^{\prime}$ and its complementary sequence for L234F substitution. Those oligonucleotide primers were synthesized by an ABI-394 DNA synthesizer (Perkin-ElmerCetus, Emerville, CA, USA). The integrity of the constructs was verified by sequencing the inserted DNA fragment. Plasmid DNA was prepared with the help of the Qiagen Mega Kit (Qiagen).

$m R N A$ expression measurement by quantitative real-time PCR (Q_RTPCR)

A fragment of $225 \mathrm{bp}$ from mouse $17 \beta-H S D 12$ was amplified with the gene-specific primers $5^{\prime}$-tgg-cac-tga-tgg-aat-tggaaa-agc- $3^{\prime}$ and $5^{\prime}$-ttc-act-aaa-acg-cca-atc-tca-aga-c- $3^{\prime}$. Using cDNA corresponding to $30 \mathrm{ng}$ of the initial total RNA, a fluorescent-based real-time PCR quantification was performed with the LightCycler Realtime PCR apparatus (Hoffman-La Roche Inc., Nutley, NJ, USA) as described 
(Luu-The et al. 2005b). Reagents were obtained from the same supplier and were used as described by the manufacturer. The conditions for the PCRs were: denaturation at $95{ }^{\circ} \mathrm{C}$ for $10 \mathrm{~s}$, annealing at $54{ }^{\circ} \mathrm{C}$ for $5 \mathrm{~s}$, and elongation at $72{ }^{\circ} \mathrm{C}$ for $10 \mathrm{~s}$. To normalize the data, we used the expression levels of the Mus musculus housekeeping gene ATP synthase. The mRNA expression levels are expressed as numbers of copies per microgram total RNA using a standard curve of $\mathrm{Cp}$ versus logarithm of the quantity as described (Luu-The et al. 2005b). The standard curve was established using known cDNA amounts of $0,10^{2}, 10^{3}, 10^{4}, 10^{5}$, and $10^{6}$ copies of cDNA from ATP synthase (primers: $5^{\prime}$-tac-tct-gct-gca-tctaag-gag-aag- $3^{\prime}$ and $5^{\prime}$-gtc-att-tag-gct-ttt-cac-ttt-gac- $3^{\prime}$ ) and a LightCycler 3.5 software provided by the manufacturer. Samples were run in triplicate and the results are expressed as mean \pm s.E.M.

\section{Results}

\section{Sequence homology between human and mouse 17 $\beta$-HSD12}

Using the sequences available in GenBank, we first compared the amino acid sequence of human and mouse $17 \beta-$ HSD 12. The alignment shows that these proteins share $81 \%$ amino acid identity. They also exhibit the conserved signatures seen in short chain dehydrogenase/reductase (SDR) family members, namely the putative YXXXK active center and the GXXXGXG consensus sequence of the cofactor-binding motif of the NADPH-preferring SDR proteins (Mazza et al. 1998). Previously, we determined that the amino acid F234 in the human enzyme plays a critical role in substrate specificity as its substitution for a smaller amino acid leads to an enzyme able to convert 4-dione into $\mathrm{T}$. It is noteworthy that the amino acid in the mouse sequence corresponding to this F234 is an $\mathrm{L}$ residue (Fig. 1).

\section{Substrate specificity of mouse $17 \beta-H S D 12$}

HEK-293 cells stably expressing $17 \beta-H S D 12$ were used to characterize the substrate specificity of the enzyme in cultured intact cells without addition of exogenous cofactor. As illustrated in Fig. 2, mouse 17 $\beta$-HSD12 catalyzes preferentially the transformation of androsterone (ADT) into $3 \alpha$-diol (38\% transformation), while the transformation of 4 -dione to $\mathrm{T}(22 \%), \mathrm{E}_{1}$ to $\mathrm{E}_{2}(25 \%)$, and dehydroepiandrosterone (DHEA) to 5-diol (22\%) are also at similar level after 24-h incubation. Similar conclusions can be observed during a longer-term (48 h) incubation with the same labeled steroids. Under comparable experimental conditions, human and monkey $17 \beta$-HSD12 mainly catalyzes the transformation of $E_{1}$ into $E_{2}$. The ability to process both androgen and estrogen steroids makes the mouse $17 \beta-$ HSD12 different from its primate homologs.

\section{L234 role in substrate preference}

We have previously shown that amino acid F234 in human $17 \beta-H S D 12$ is responsible for the selectivity of this enzyme for estrogen (Luu-The et al. 2006). Indeed, due to its large size, this amino acid prevents, by steric hindrance, C19steroids from entering the active site. It is interesting to note that in the homolog $17 \beta-$ HSD3 that catalyzes specifically the transformation of androgen, the corresponding amino acid is A, the second smallest natural amino acid. Since the corresponding amino acid in the mouse sequence is an $\mathrm{L}$ residue that has much smaller size than the $\mathrm{F}$ found in human 17 $\beta$-HSD12, we investigated whether the loss of estrogenic specificity in the mouse enzyme when compared with human is due to this amino acid. We thus performed site-directed mutagenesis to substitute the $\mathrm{L}$ residue for $\mathrm{A}$ and $\mathrm{F}$ found in $17 \beta-H S D 3$ and $17 \beta-H S D 12$ respectively. As illustrated in Fig. 3, the ability of the L234F substitution to transform 4-dione is much lower than the one observed with the wildtype enzyme or the L234A substitution.

\section{Tissue distribution of mouse $17 \beta$-HSD12}

We then examined the tissue distribution of $17 \beta-H S D 12$ mRNA in 23 mouse tissues, namely the adrenal, liver, colon, kidney, stomach, lung (bronchi), pituitary gland, thymus, spleen, heart, gastrocnemius, preputial gland, epididymis, testis, prostate, seminal vesicle, clitoral gland, fat (retroperitoneal), mammary gland, uterus, vagina, ovary, and oviduct using quantitative real-time PCR. As illustrated in Fig. 4 , mouse $17 \beta-H S D 12$ mRNA is ubiquitously expressed in all those tissues. In the male, the highest level of expression of $17 \beta-$ HSD12 mRNA is seen in the preputial gland, retroperitoneal fat, and adrenal. In the female, mouse $17 \beta-H S D 12$ is highly expressed in the clitoral gland, retroperitoneal fat, and mammary gland. Moreover, it is interesting to note that the expression level of this enzyme in the male preputial gland, retroperitoneal fat, and adrenal is much higher than in the female clitoral gland, retroperitoneal fat, and adrenal.

\section{Discussion}

In this report, we show that mouse $17 \beta-H S D 12$ catalyzes efficiently the transformation of C19- as well as C18-steroids, in contrast with the human and primate enzymes that catalyze selectively the transformation of $E_{1}$ into $E_{2}$. This difference is in part due to the presence of a Leu residue at position 234 in the mouse enzyme. Because of its relatively small size, this amino acid does not exert steric hindrance toward entrance of C19-steroids in the binding site. On the other hand, a bulky Phe residue at this position causes major steric hindrance in both the human and monkey enzymes. Interestingly, human and monkey $17 \beta-$ HSD3 possess an Ala residue that allows the enzyme to transform efficiently 4-dione into $\mathrm{T}$ due to its 
m17 $\beta$-HSD12

h17 $\beta$-HSD12

$\operatorname{mk17} \beta-\mathrm{HSD} 12$

m $17 \beta-H S D 3$

h17 $\beta$-HSD3

mk17 $\beta$-HSD3

$\operatorname{m17} \beta-\mathrm{HSD} 12$

h $17 \beta-H S D 12$

mk17 $\beta$-HSD12

m $17 \beta-H S D 3$

h $17 \beta-$ HSD 3

mk17 $\beta$-HSD3

m17 $\beta$-HSD12

h17 $\beta-$ HSD12

mk17 $\beta$-HSD12

m17 $\beta$-HSD3

h17 $\beta$-HSD3

mk17 $\beta$-HSD3

m17 $\beta$-HSD12

h17 $\beta$-HSD1 2

mk17 $\beta$-HSD12

$\mathrm{m} 17 \beta-\mathrm{HSD} 3$

h17 $\beta$-HSD3

mk17 $\beta$-HSD3

m17 $\beta$-HSD12

h17 $\beta$-HSD12

mk17 $\beta$-HSD12

m17 $\beta$-HSD 3

h17 $\beta$-HSD3

mk17 $\beta$-HSD3

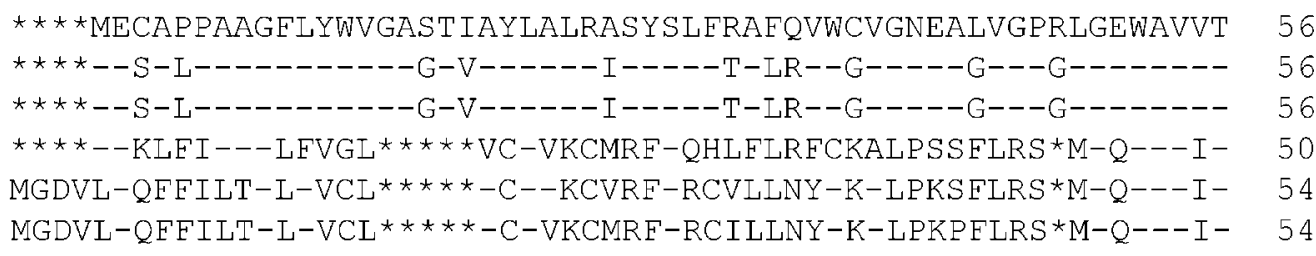

GGTDGIGKAYAEELAKRGMKIVLISRSQDKLNQVSNNIKEKFNVETRTIAVDFSLDDIYD

-S------S-------H---V------K---D---SE-----K----------ASE----

$-\mathrm{G}------\mathrm{S}-----------\mathrm{V}------\mathrm{Q}---\mathrm{D}---\mathrm{SE}-----\mathrm{K}----------\mathrm{T}-\mathrm{E}----$

-AG-------SE---RH-LNV-----TLE--QTIAEE-ERTTGSGVKIVQA--TRE----

-AG-------SE------LNV-----TLE--EAIATE-ERTTGRSVKI-QA--TK----E

-AS-------SE---R--LDV-----MLE--QATATE-ERTTGRSVKI-QA--TK----E

KIKTGLSGLEIGVLVNNVGMS *YEYPEYFLEIPDLDNTIKKLININVLSVCKVTRLVLPG $------\mathrm{A}-----\mathrm{I}--------\star--------\mathrm{DV}-----\mathrm{V}---\mathrm{M}----\mathrm{I}-----\mathrm{M}-\mathrm{Q}-----$

$------\mathrm{A}-----\mathrm{I}--------\star-------D \mathrm{DV}-----\mathrm{V}---\mathrm{M}----\mathrm{I}-----\mathrm{M}-\mathrm{Q}-----$

$\mathrm{H}--\mathrm{EH}-\mathrm{E}---\mathrm{N}-\mathrm{I}-------\mathrm{LPSEF}-\mathrm{SH}--\mathrm{SSSGE} * \star * \mathrm{SQN}--\mathrm{HC}-\mathrm{IT}--\mathrm{V}-\mathrm{M}-\mathrm{Q}---\mathrm{KH}$

$\mathrm{H}--\mathrm{EK}-\mathrm{A}-----\mathrm{I}-------\mathrm{LPNLI}-\mathrm{SH}--\mathrm{NA}--\mathrm{E} * \star \star \star-Q S--H C-I T--\mathrm{V}-\mathrm{M}-\mathrm{Q}-\mathrm{I}-\mathrm{KH}$

$\mathrm{H}--\mathrm{EK}-\mathrm{T}-----\mathrm{I}-------\mathrm{LPNL} \mathrm{L}-\mathrm{SH}--\mathrm{NA}--\mathrm{E} * * \star-\mathrm{QSV}-\mathrm{HC}-\mathrm{IT}--\mathrm{V}-\mathrm{M}-\mathrm{Q}-\mathrm{I}-\mathrm{KH}$

116

116

116

110

114

114

175

175

175

167

171

171

MVERSKGVILNISSASGMLPVPLITIYSATKAFVDFFSQCLHEEYKSKGIFVQSVMPYLV 235

-------A------G----------------T-------------R---V-----L--F- 235

-------A------G---F------------T-------------R---------L--F- 235

-ES-R--I------GAALR-W--YSL---S----YT--KA-SV--RD---II-VLT--SI 227

-ES-Q--I------GIALE-W--YSM---S----CA--KA-Q----A-EVII-VLT--A- 231

-ES-R--I------GIALE-W--YSM---S----CT--KA-Q---RA-EVII-VLT--A- 231

ATKLAKIQKPTLDKPSAETFVKSAIKTVGLQTRTTGYVIHSLMGS INS IMPRWMYFKIIM 295

$-------\mathrm{R}--------\mathrm{P}--------------\mathrm{S}--\mathrm{N}--\mathrm{L}--\mathrm{A}-----\mathrm{I}-\mathrm{NL}-\mathrm{S}-\mathrm{I}-\mathrm{L}--\mathrm{V}-295$

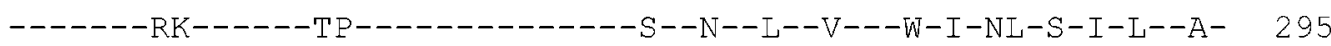

S-PMT-YLN*NKMTKT-DE---ESL-Y-TIGAESC-CLA-EIIAI-LNRI-SRIFYSSTA 286

S-AMT-YLNTNVITKT-DE---ESLNY-TIGGE-C-CLA-EILAGF--LI-A-AFYSGAF 291

S-AMT-YLNTNVITKT-DE--QESLNY-TIGGE-C-CLA-EILAGFL-LI-A-AFYSGAF 291

m17 $\beta-$ HSD12 G*FSKSLRNRYLKKRKKN* 312

h17 $\beta-$ HSD12 $\quad \mathrm{N}^{\star} \mathrm{MN}--\mathrm{T}-\mathrm{AH}----\mathrm{T}---\star \quad 312$

mk17 $\beta-H S D 12 \quad N^{*} M N-A T-V H----I--* \star \quad 312$

m17 3 -HSD3 QR-LLTRYSD---RNIS-R 305

h17 $3-$ HSD3 QRLLLTHYVA---LNT-VR 310

mk17 $\beta$-HSD3 QRLLLTHYVA---LNT-VR 310

Figure 1 Amino acid sequence comparison of the mouse, human, and monkey $17 \beta-$ HSD12 and $17 \beta$-HSD3. The amino acid sequences of the mouse $17 \beta-$ HSD1 2 and $17 \beta-$ HSD3 are aligned with their primate homologs. Amino acid sequences are presented in conventional single letter code and numbered on the right. Dashes represent identical amino acids, while asterisks $\left({ }^{*}\right)$ show the gaps resulting from the alignment. The conserved sequences for the active (YXXXK) and cofactor-binding (GXXXGXG) sites of the NADPH-preferring SDR proteins (Mazza et al. 1998 ) as well as the amino acid number 234 suspected for the substrate specificity in the 17ß-HSD12 are underlined.

smaller size. However, the molecular cause of $17 \beta-$ HSD3 inability to metabolize C18-steroids is still unknown.

The mRNA tissue distribution analysis performed by quantitative real-time PCR indicates that mouse $17 \beta-$ HSD12 is distributed ubiquitously in numerous sexual tissues and adrenal gland, thus suggesting a central role in androgen and estrogen synthesis in this organism. Adipose tissue is now considered as an important endocrine organ, which is a major site for metabolism of sex steroids (Kershaw \& Flier 2004, Blouin et al. 2006) and interestingly, the retroperitoneal fat 


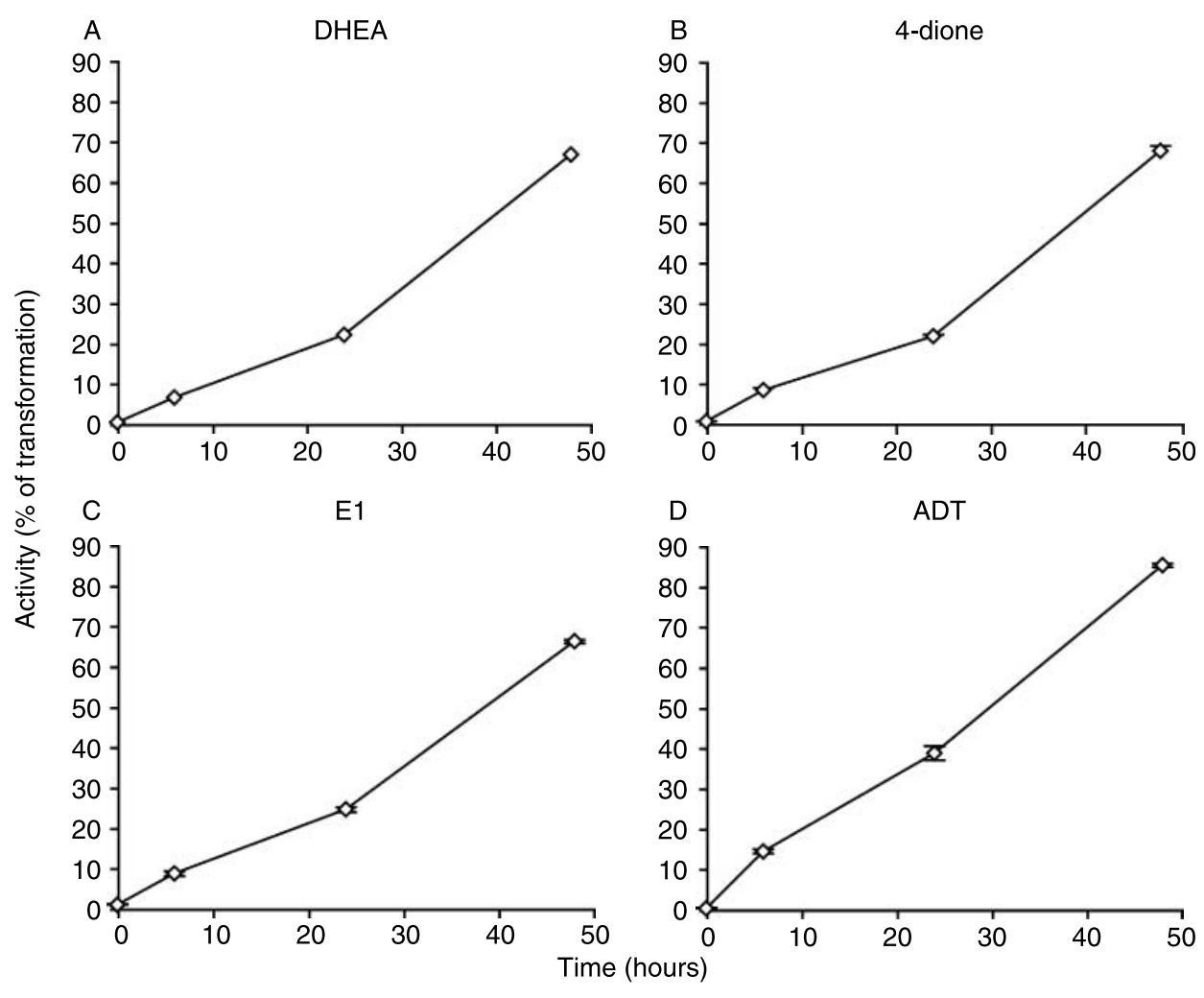

Figure 2 Substrate specificity of HEK-293 cells stably transfected with mouse $17 \beta-H S D 12$. Different $\left({ }^{14} \mathrm{C}\right)$ labeled steroids (DHEA (A), 4-dione (B), $E_{1}(C)$ and ADT (D)) were added to freshly changed culture medium at a concentration of $0 \cdot 1 \mu \mathrm{M}$. After $0,6,24$, and $48 \mathrm{~h}$ of incubation, the media were collected to extract steroids. Metabolites were quantified as described under Materials and Methods. Non-transfected HEK-293 cells were used as controls. The data are expressed as mean \pm s.E.M. of triplicate measurements.

exhibits a high level of 17ß-HSD12 mRNA. This finding emphasizes the importance of enzyme in numerous steroidogenic organs.

The different characteristics of mouse and human steroidogenic enzymes strongly suggest that sex steroid biosynthesis and their modes of action are very different in these two species. The mouse adrenal does not express P450c17 (Luu-The et al. 2005a) and thus does not produce androgen adrenal precursors (DHEA and 4-dione) for the biosynthesis of active androgen and estrogen like the human and primate, which produce large amount of adrenal precursors. Consequently, sex steroids in the mouse are produced almost exclusively by the gonads. Hence, upon gonadectomy, the size of androgen- and estrogen-sensitive organs such as the prostate and uterus is reduced drastically. However, administration of an inactive steroid precursor to gonadectomized mice brings back the prostate and uterus to a normal size. The latter observation indicates that despite the fact that local production of active steroids in peripheral tissues is minimally active in rodents, due to the very low level of adrenal precursors, evolution has already put in place an enzymatic structure necessary for their production. This system becomes highly active in the human and primate that possess high circulating levels of these steroid precursors. Indeed, sex steroid formation in peripheral target tissues (intracrinology) accounts for $40-50 \%$ of active androgens in the human prostate (Labrie 1991). Many observations clearly demonstrate that there are

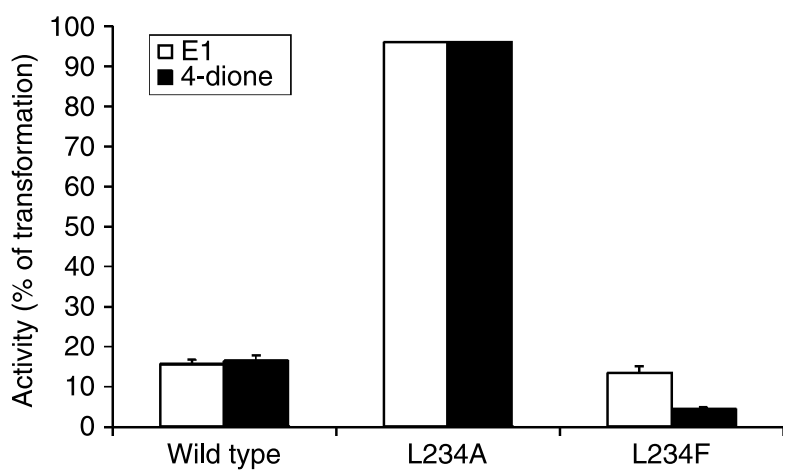

Figure 3 Effects of L234A and L234F amino acid substitutions on mouse $17 \beta$-HSD12 activity. HEK-293 cells were transiently transfected with the expression vectors encoding mouse $17 \beta-\mathrm{HSD} 12$ (wild-type) and mutants in which the $L$ at amino acid position 234 has been substituted with either $\mathrm{A}$ or $\mathrm{F}$ (L234A and L234F respectively). The ability of transfected cells to convert $E_{1}$ into $E_{2}$ and 4-dione into $T$ was determined as described under Materials and Methods. 

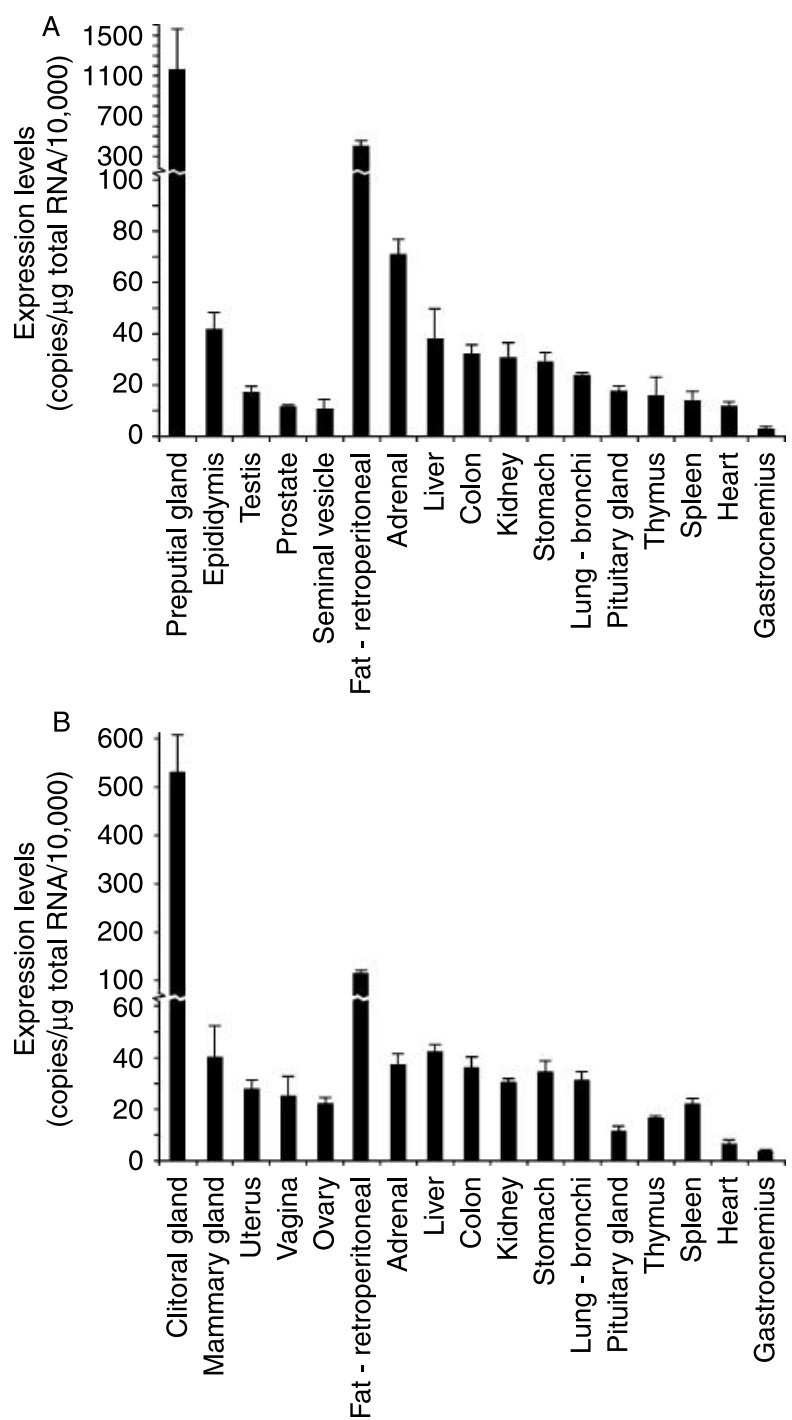

Figure 4 Tissue mRNA expression levels of mouse 17ß-HSD12 measured by real-time PCR. The mRNA expression levels were quantified in the indicated (A) male and (B) female tissues using real-time PCR. Real-time PCR was performed as described under Materials and Methods. Results are expressed as mean \pm s.E.M. of triplicate measurements.

additional steroid hormone sources other than gonads. For example, in men having their testicles surgically removed or in whom androgen testicular secretion is blocked by treatment with a luteinizing hormone releasing hormone (LHRH) agonist, it is observed that despite a 90-95\% decrease of T levels in the blood, intraprostatic DHT concentration is decreased by only $50 \%$. Further evidence lies in the normal development of secondary sexual characteristics in boys deficient in type $23 \beta$ HSD. In that case, the conversion of DHEA into active steroids via type $13 \beta$-HSD, expressed in peripheral tissues, is responsible for the apparition of those secondary sexual characteristics. Furthermore, the cloning of multiple genes encoding isoforms of steroidogenic enzymes in the human, namely types 1 and $23 \beta$-HSD (Luu The et al. 1989, Lachance et al. 1990, 1991, Rhéaume et al. 1991, Rheaume et al. 1992), types 1 to $1217 \beta$-HSDs (Peltoketo et al. 1988, Luu The et al. 1989), as well as types 1 and $25 \alpha$-reductases (Andersson et al. 1991, Labrie et al. 1992), and 3 $\alpha$-HSDs (Cheng et al. 1991, Dufort et al. 2001) advocate for the existence of a local biosynthesis in peripheral tissues. During recent years, inhibitors of steroidogenic enzymes have already led to the development of some interesting therapeutic compounds. For example, Proscar (Merck-Frost), an inhibitor of $5 \alpha$-reductase, has been used to treat successfully androgen-sensitive diseases such as alopecia (Van Neste et al. 2000), hirsutism (Fruzzetti et al. 1999), and benign prostatic hyperplasia (Ekman 1999). More recently, inhibitors of aromatase have been shown to be highly efficient in breast cancer therapy (Buzdar 2000, Howell et al. 2003, Goss \& Strasser-Weippl 2004). The gene encoding aromatase is a single gene having many alternative promoters allowing a tissue-specific expression of different transcripts encoding the same protein (Simpson et al. 1994, 1997). On the other hand, estrogenic 17 $\beta$-HSDs (types 1, 7, and $1217 \beta$ HSD) possess very different primary structures, sharing only $\sim 20 \%$ amino acids identity. These enzymes could represent more tissue-specific drug targets than aromatase for the treatment of estrogen-sensitive diseases such as breast cancers.

\section{Acknowledgements}

We would like to thank Nathalie Paquet, Guy Reinmitz, and Melanie Robitaille for their skillful technical assistance. This work was financially supported by the Canadian Institute of Health Research (CHIR) (Grant No MOP-77698 to Van LuuThe). Pierre-Gilles Blanchard is supported by a studentship from the Fonds de la Recherche en Santé du Québec (FRSQ). The authors declare that there is no conflict of interest that would prejudice the impartiality of this scientific work.

\section{References}

Andersson S, Berman DM, Jenkins EP \& Russell DW 1991 Deletion of steroid $5 \alpha$-reductase 2 gene in male pseudohermaphroditism. Nature 354 159-161.

Blouin K, Richard C, Brochu G, Hould FS, Lebel S, Marceau S, Biron S, LuuThe V \& Tchernof A 2006 Androgen inactivation and steroid-converting enzyme expression in abdominal adipose tissue in men. Journal of Endocrinology 191 637-649.

Buzdar A 2000 Exemestane in advanced breast cancer. Anticancer Drugs 11 609-616.

Cheng KC, White PC \& Qin KN 1991 Molecular cloning and expression of rat liver $3 \alpha$-hydroxysteroid dehydrogenase. Molecular Endocrinology $\mathbf{5}$ 823-828.

Dufort I, Rheault P, Huang X-F, Soucy P \& Luu-The V 1999 Characteristics of a highly labile human type $517 \beta$-hydroxysteroid dehydrogenase. Endocrinology 140 568-574.

Dufort I, Labrie F \& Luu-The V 2001 Human types 1 and $33 \alpha$-hydroxysteroid dehydrogenases: differential lability and tissue distribution. Journal of Clinical Endocrinology and Metabolism 86 841-846. 
Ekman P 1999 Finasteride in the treatment of benign prostatic hypertrophy: an update. New indications for finasteride therapy. Scandinavian Journal of Urology and Nephrology 203 15-20.

Fruzzetti F, Bersi C, Parrini D, Ricci C \& Genazzani AR 1999 Treatment of hirsutism: comparisons between different antiandrogens with central and peripheral effects. Fertility and Sterility $\mathbf{7 1} 445-451$.

Ghersevich S, Nokelainen P, Poutanen M, Orava M, Autio-Harmainen H, Rajaniemi H \& Vihko R 1994a Rat 17ß-hydroxysteroid dehydrogenase type 1: primary structure and regulation of enzyme expression in rat ovary by diethylstilbestrol and gonadotropins in vivo. Endocrinology 135 1477-1487.

Ghersevich S, Poutanen M, Tapanainen J \& Vihko R 1994b Hormonal regulation of rat $17 \beta$-hydroxysteroid dehydrogenase type 1 in cultured rat granulosa cells: effects of recombinant follicle-stimulating hormone, estrogens, androgens, and epidermal growth factor. Endocrinology 135 1963-1971.

Gibori G, Khan I, Warshaw ML, McLean MP, Puryear TK, Nelson S, Durkee TJ, Azhar S, Steinschneider A \& Rao MC 1988 Placental-derived regulators and the complex control of luteal cell function. Recent Progress in Hormone Research 44 377-429.

Goss PE \& Strasser-Weippl K 2004 Prevention strategies with aromatase inhibitors. Clinical Cancer Research 10 372S-379S.

Howell A, Robertson JF \& Vergote I 2003 A review of the efficacy of anastrozole in postmenopausal women with advanced breast cancer with visceral metastases. Breast Cancer Research and Treatment 82 215-222.

Huang XF \& Luu-The V 2000 Molecular characterization of a first human $3(\alpha \rightarrow \beta)$-hydroxysteroid epimerase. Journal of Biological Chemistry 275 29452-29457.

Kershaw EE \& Flier JS 2004 Adipose tissue as an endocrine organ. Journal of Clinical Endocrinology and Metabolism 89 2548-2556.

Labrie F 1991 Intracrinology. Molecular and Cellular Endocrinology 78 C113-C118.

Labrie F, Sugimoto Y, Luu-The V, Simard J, Lachance Y, Bachvarov D, Leblanc G, Durocher F \& Paquet N 1992 Structure of human type II $5 \alpha$-reductase gene. Endocrinology 131 1571-1573.

Lachance Y, Luu-The V, Labrie C, Simard J, Dumont M, de Launoit Y, Guérin S, Leblanc G \& Labrie F 1990 Characterization of human $3 \beta$-hydroxysteroid dehydrogenase $/ \Delta^{5}-\Delta^{4}$ isomerase gene and its expression in mammalian cells. Journal of Biological Chemistry 265 20469-20475.

Lachance Y, Luu-The V, Verreault H, Dumont M, Rhéaume É, Leblanc G \&

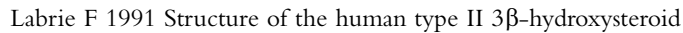
dehydrogenase $/ \Delta^{5}-\Delta^{4}$ isomerase $(3 \beta-H S D)$ gene: adrenal and gonadal specificity. DNA and Cell Biology 10 701-711.

Liu H, Robert A \& Luu-The V 2005 Cloning and characterization of human form 2 type $717 \beta$-hydroxysteroid dehydrogenase, a primarily $3 \beta$-keto reductase and estrogen activating and androgen inactivating enzyme. Journal of Steroid Biochemistry and Molecular Biology 94 173-179.

Liu H, Zheng S, Bellemare V, Pelletier G, Labrie F \& Luu-The V 2007 Expression and localization of estrogenic type $1217 \beta$-hydroxysteroid dehydrogenase in the cynomolgus monkey. BMC Biochemistry 82.

Luu-The V 2001 Analysis and characteristics of multiple types of human $17 \beta$-hydroxysteroid dehydrogenases. Journal of Steroid Biochemistry and Molecular Biology 76 143-151.

Luu The V, Labrie C, Zhao HF, Couet J, Lachance Y, Simard J, Leblanc G, Cote J, Berube D, Gagne R et al. 1989 Characterization of cDNAs for human estradiol $17 \beta$-dehydrogenase and assignment of the gene to chromosome 17: evidence of two mRNA species with distinct $5^{\prime}$-termini in human placenta. Molecular Endocrinology 3 1301-1309.

Luu-The V, Pelletier G \& Labrie F 2005a Quantitative appreciation of steroidogenic gene expression in mouse tissues: new roles for type 2 $5 \alpha$-reductase, $20 \alpha$-hydroxysteroid dehydrogenase and estrogen sulfotransferase. Journal of Steroid Biochemistry and Molecular Biology 93 269-276.

Luu-The V, Paquet N, Calvo E \& Cumps J 2005 Improve real-time RT-PCR method for high throughput measurements using second derivative calculation and double correction. BioTechniques 32 287-293.
Luu-The V, Tremblay P \& Labrie F 2006 Characterization of type 12 $17 \beta$-hydroxysteroid dehydrogenase, an isoform of type $317 \beta$-hydroxysteroid dehydrogenase responsible for estradiol formation in women. Molecular Endocrinology 20 437-443.

Marijanovic Z, Laubner D, Moller G, Gege C, Husen B, Adamski J \& Breitling R 2003 Closing the gap: identification of human 3-ketosteroid reductase, the last unknown enzyme of mammalian cholesterol biosynthesis. Molecular Endocrinology 17 1715-1725.

Mazza C, Breton R, Housset D \& Fontecilla-Camps JC 1998 Unusual charge stabilization of NADP + in $17 \beta$-hydroxysteroid dehydrogenase. Journal of Biological Chemistry 273 8145-8152.

Mindnich R, Moller G \& Adamski J 2004 The role of 17ß-hydroxysteroid dehydrogenases. Molecular and Cellular Endocrinology 218 7-20.

Moon YA \& Horton JD 2003 Identification of two mammalian reductases involved in the two-carbon fatty acyl elongation cascade. Journal of Biological Chemistry 278 7335-7343.

Mustonen MV, Poutanen MH, Isomaa VV, Vihko PT \& Vihko RK 1997 Cloning of mouse $17 \beta$-hydroxysteroid dehydrogenase type 2 , and analysing expression of the mRNAs for types 1, 2, 3, 4 and 5 in mouse embryos and adult tissues. Biochemical Journal 325 199-205.

Van Neste D, Fuh V, Sanchez-Pedreno P, Lopez-Bran E, Wolff H, Whiting D, Roberts J, Kopera D, Stene JJ, Calvieri S et al. 2000 Finasteride increases anagen hair in men with androgenetic alopecia. British Journal of Dermatology $143804-810$.

Nokelainen P, Peltoketo H, Vihko R \& Vihko P 1998 Expression cloning of a novel estrogenic mouse $17 \beta$-hydroxysteroid dehydrogenase/17-ketosteroid reductase (m17HSD7), previously described as a prolactin receptorassociated protein (PRAP) in rat. Molecular Endocrinology 12 1048-1059.

Peltoketo H, Isomaa V, Maentausta O \& Vihko R 1988 Complete amino acid sequence of human placental 17 $\beta$-hydroxysteroid dehydrogenase deduced from cDNA. FEBS Letters 239 73-77.

Peltoketo H, Luu-The V, Simard J \& Adamski J 1999 17ß-Hydroxysteroid dehydrogenase (HSD)/17-ketosteroid reductase (KSR) family; nomenclature and main characteristics of the 17HSD/KSR enzymes. Journal of Molecular Endocrinology 23 1-11.

Rhéaume É, Lachance Y, Zhao H-F, Breton N, Dumont M, de Launoit Y, Trudel C, Luu-The V, Simard J \& Labrie F, 1991 Structure and expression of a new complementary DNA encoding the almost exclusive $3 \beta$-hydroxysteroid dehydrogenase $/ \Delta^{5}-\Delta^{4}$-isomerase in human adrenals and gonads. Molecular Endocrinology 5 1147-1157.

Rheaume E, Simard J, Morel Y, Mebarki F, Zachmann M, Forest MG, New MI \& Labrie F 1992 Congenital adrenal hyperplasia due to point mutations in the type II $3 \beta$-hydroxysteroid dehydrogenase gene. Nature Genetics 1 239-245.

Sawetawan C, Milewich L, Word RA, Carr BR \& Rainey WE 1994 Compartmentalization of type I $17 \beta$-hydroxysteroid oxidoreductase in the human ovary. Molecular and Cellular Endocrinology 99 161-168.

Simpson ER, Mahendroo MS, Means GD, Kilgore MW, Hinshelwood MM, Graham-Lorence S, Amarneh B, Ito Y, Fisher CR, Michael MD et al. 1994 Aromatase cytochrome P450, the enzyme responsible for estrogen biosynthesis. Endocrine Reviews 15 342-355.

Simpson ER, Michael MD, Agarwal VR, Hinshelwood MM, Bulun SE \& Zhao Y 1997 Cytochromes P450 11: expression of the CYP19 (aromatase) gene: an unusual case of alternative promoter usage. FASEB Journal 11 29-36.

Torn S, Nokelainen P, Kurkela R, Pulkka A, Menjivar M, Ghosh S, CocaPrados M, Peltoketo H, Isomaa V \& Vihko P 2003 Production, purification, and functional analysis of recombinant human and mouse 17ß-hydroxysteroid dehydrogenase type 7. Biochemical and Biophysical Research Communications 305 37-45.

Received in final form 16 May 2007

Accepted 19 May 2007

Made available online as an Accepted Preprint 25 May 2007 